13. Rizzo C. Possible role of ABO system in age-related diseases and longevity: a narrative review / C. Rizzo, C. Caruso, S. Vasto // Immunity \& Ageing. - 2014. - V.11. - P. 16-23.

14. The challenges in moving from ageing to successful longevity / G. Kolovou, N. Barzilai, C. Caruso [et al.] // Curr. Vasc. Pharmacol. - 2014. - V.12. - P. 659-661.

15. The Haptoglobin 1 Allele Correlates With White Matter Hyperintensities in Middle-Aged Adults With Type 1 Diabetes / T. Costacou, C. Rosano, H. Aizenstein [et al.] // Diabetes. - 2015. - V. 64. - P. 654-659.

Соколенко Вадим. Значение генетических систем ABO, Rh и Hр в стресс-индуцированной иммунореактивности обитателей территорий, загрязненных радионуклидами. Исследовали значение иммуногенетических систем AB0, Rh и Нр в динамике показателей иммунной системы обитателей территорий, загрязненных радионуклидами, в условиях психоэмоциональной нагрузки. Оценивали влияние экзаменационной сессии на естественную резистентность студентов, приехавших на учебу из IV радиационной зоны, а также эффективность процесса восстановления. Установили, что у обследованных наблюдается существенное угнетение Т-клеточного звена иммунитета, с выходом показателей за пределы нормы. На выраженность супрессии и эффективность восстановительного процесса влияли иммуногенетические факторы крови, особенно, эритроцитарная система АВ0 и сывороточная система гаптоглобина Нр. Наиболее прессинговыми являются сочетания фенотипов 0(I) и В(III) системы AB0, негативного фенотипа системы «Rhesus» и фенотипа Нр2-2 гаптоглобина. Протекторная тенденция наиболее выражена при сочетании фенотипов A(I), Rh+ и Hp2-2.

Ключевые слова: генетические системы крови, ЧАЭС, стресс, иммунитет.

Sokolenko Vadym. The Value of Genetic Systems ABO, Rh and Hp in Stress-induced Immunoreactivity Among Residents Living in the Areas Contaminated With Radionuclides. We studied the importance of immunogenetic systems $\mathrm{AB} 0, \mathrm{Rh}$ and $\mathrm{Hp}$ in dynamics of immune system work among residents of the areas contaminated with radionuclides, under conditions of emotional stress. The impact of examinations on the natural resistance of students who arrived for studying from the IV radiation zone and also the efficiency of recovery were evaluated. We discovered a significant inhibition of T-cell immunity with the norm overrun among examined patients. Suppression intensity and effectiveness of restorative process are influenced by immunogenetic factors of blood, especially erythrocytic system AB0 and serum haptoglobin Hp. The most pressing is a combination of phenotypes 0 (I) and B(III) in system AB0, negative phenotype «Rhesus» and haptoglobin phenotype Hp2-2. Protective trend is most pronounced in combination of phenotypes A(II), Rh + and Hp2-2.

Key words: genetic blood system, Chernobyl, stress, immunity.

Стаття надійшла до редколегії 12.04.2016 p.

УДК 612.017:37.091.212-055.2

Оксана Добростан,
Олександр Плиска,
Наталія Філімонова

\title{
Адаптаційні реакції організму студенток із різною масою тіла в динаміці першого року навчання
}

Для дослідження адаптаційних реакцій із студенток першого курсу НПУ ім. М. П. Драгоманова сформовано дві групи: I склали студентки з нормальною масою тіла, II - студентки з надмірною масою тіла. Порівняльний аналіз показників варіабельності серцевого ритму студенток із різним IMT на кожному етапі дослідження виявив: починаючи з другого етапу, у студенток II групи, порівняно з I, значуще менш виражений тонус ПВ ВНС, менш адекватне функціонування серця, більша централізація управління серцевим ритмом. Результати наших досліджень указують на те, що в II групі, порівняно з I, напруження регуляторних механізмів було значуще більшим упродовж першого навчального року, а отже, «фізіологічна ціна адаптації» вища.

Ключові слова: адаптація, регуляторні механізми, ступінь напруження, студентки.

Постановка наукової проблеми та ії значення. Однією з глобальних проблем суспільства, яка призводить до зниження рівня здоров’я й працездатності населення є проблема надмірної маси тіла

(C) Добростан О., Плиска О., Філімонова Н., 2016 
$[13$, c. 50]. Згідно зі статистичними даними, серед працездатного населення України ожиріння виявлено у 26 \% випадків, а надмірну масу тіла - у близько 36 \% усього населення України [8, с. 32, 13 , с. 50]. При чому поширеність ожиріння серед жінок в 1,7 раза вища, ніж серед чоловіків [9, с. 62]. Крім того, в Україні щорічно фіксують 18-20 тис. нових випадків ожиріння серед дітей, підлітків і молоді $[5$, с. 50]. А за даними ряду науковців, щорічне збільшення кількості студентів, хворих на ожиріння, зі зростанням курсу складає $1 \%$ [11, с. 80]. Відхилення маси тіла від норми має суттєве значення в ситуаціях, які ставлять підвищені вимоги до організму людини. Зокрема, до таких ситуацій належать вступ та адаптація студентів до нових умов навчання у ВНЗ. Особливо це стосується першокурсників, організм яких намагається адаптуватися до нових для нього умов [14, с.43]. Так, у процесі навчання в студенток першого курсу виявлено підвищення діастолічного артеріального тиску, але в межах норми, підвищення ступеня централізації регуляторних механізмів ритму серця при задовільних резервах серцево-судинної системи [2, с. 34]. Адаптація студентів першого курсу до навчальної діяльності розцінюється як перехід від середнього нормального рівня функціонування до нестійкого, неповного пристосування, активного пошуку стійкого стану [7, с.197]. I тому з'ясування впливу фактора маси тіла на перебіг адаптаційних реакцій має важливе значення для наукового обгрунтування необхідності розробки індивідуальних заходів профілактики психосоматичних захворювань для такої категорії студентів, адже більшість сучасних дослідників указують на те, що зберегти й зміцнити здоров'я студентів можливо, лише врахувавши індивідуальні особливості в процесі навчання [12].

Відомо, що адаптаційні реакції індивідуальні та реалізуються в різних осіб із різним ступенем участі функціональних систем. У роботах Р. М. Баєвського і його співробітників $[3,4]$ установлений зв'язок варіабельності ритму серця з нейрогуморальною регуляцією й адаптивними реакціями організму людини на стрес. Отже, аналіз варіабельності серцевого ритму забезпечує отримання інформації про ступінь напруження регуляторних систем, що дає підству робити висновки про характер адаптаційних процесів, зокрема і в студентів [4, 7, с. 196]. Тому мета дослідження полягала у вивченні адаптаційних реакцій організму студенток із різною масою тіла в динаміці першого року навчання на основі аналізу ступеня напруження регуляторних систем.

Виклад основного матеріалу й обгрунтування отриманих результатів дослідження. Для оцінки ступеня надмірної маси тіла чи ії дефіциту використовували уніфікований показник Індекс маси тіла, запропонований експертами Всесвітньої організації охорони здоров'я в 1997 р. й модифікований у 1999 р., що визначається за такою формулою:

де $\mathrm{m}$ - маса тіла, $\mathrm{h}$ - зріст.

$$
\mathrm{IMT}=\mathrm{m}(\kappa \Gamma) / \mathrm{h}^{2}\left(\mathrm{M}^{2}\right),
$$

Ураховуючи IMT із студенток (17-18 років) першого курсу денної форми навчання Інституту природничо-географічної освіти та екології НПУ ім. М. П. Драгоманова сформовано дві групи досліджуваних (табл. 1).

Таблиия 1

Поділ досліджуваних на групи

\begin{tabular}{|c|l|c|c|c|}
\hline \multirow{2}{*}{ o 3/ } & \multicolumn{1}{|c|}{ Назва групи } & $\begin{array}{c}\text { Скорочене } \\
\text { позначення }\end{array}$ & $\begin{array}{c}\text { Кількість } \\
\text { досліджуваних }\end{array}$ & $\begin{array}{c}\text { IMT, } \\
\boldsymbol{\kappa z}^{2} \boldsymbol{M}^{2}\end{array}$ \\
\hline 1 & Група 3 нормальною масою тіла & I & 54 & від 19 до 24,5 \\
\hline 2 & Група 3 надмірною масою тіла & II & 32 & від 25 до 29,9 \\
\hline
\end{tabular}

Досліджувані, за даними медичного обстеження, були практично здоровими. Усі особи добровільно брали участь в експерименті. Плани проведення та організація досліджень схвалені комісією 3 біоетичної експертизи НПУ ім. М. П. Драгоманова.

Дослідження проводили в дні високої розумової працездатності (вівторок, середу, четвер) із 9-00 до 12-30 у стандартних умовах, при постійній освітленості 100 лк, температурі повітря на рівні 20$22^{\circ} \mathrm{C}$, у шість етапів: на початку навчального року - 1-ше вимірювання (результати якого взято за контроль), друге - проводили в середині першого семестру (кінець жовтня), третє - у кінці першого семестру (середина грудня), четверте - на початку другого семестру (перший тиждень лютого), п’яте - у середині другого навчального семестру (кінець березня), шосте - у кінці навчального року (кінець травня). В обстежуваних реєстрували ЕКГ. Реєстрацію ЕКГ, розрахунок ритмограм та обчислення 
показників варіаційної пульсометрії проводили за допомогою цифрового одноканального електрокардіографа ЭК1Т - 1/3 - 07 АКСИОН, Росія. Досліджували такі показники: моду (Мо), амплітуду моди (AMo), варіаційний розмах (BP), індекс напруження (Інапр.), індекс вегетативної рівноваги (IBP), показник адекватності процесів регуляції (ПАПР).

Статистичний аналіз даних проводили за допомогою пакета STATISTICA 6.0 (StatSoft, USA, 2001). Нормальність розподілів змінних перевіряли, застосовуючи тести Шапіро-Вілка. Оскільки всі субтести проходили одні й ті самі обстежувані в різні моменти часу, а розподіл практично всіх параметрів за критерієм Шапіро-Вілка був відмінним від нормального ( $<0,05)$, то вплив маси тіла на показники варіаційної пульсометрії досліджували за критерієм Крускал-Уоліса ANOVA. Для визначення впливу часу на показники варіаційної пульсометрії використовували критерій Фрідмана ANOVA. Для з'ясування того, у чому саме проявляється вплив указаних факторів, оскільки розподіл практично всіх параметрів був відмінний від нормального ( $<0,05)$, для порівняння двох залежних вибірок застосовано критерій Вілкоксона, для порівняння двох не залежних вибірок застосовано критерій Манна-Уітні. Для опису вибіркового розподілу вказували медіану $\left(\mathrm{M}_{\mathrm{e}}\right)$ і нижній $(25 \%)$ та верхній (75 \%) квартилі: $\mathrm{M}_{\mathrm{e}}[25 \% ; 75 \%]$.

Провівши дослідження показників варіабельності серцевого ритму в студенток I групи, отримали такі результати (табл. 2). Отримані нами дані погоджуються з даними, отриманими А. О. Ісаковим В. П. Ляшенком, Г. С. Петровим при дослідженні студенток першого курсу природничих спеціальностей Дніпропетровського національного університету імені Олеся Гончара [10].

Таблиия 2

Показники варіабельності серцевого ритму студенток з нормальною масою тіла в динаміці першого семестру

\begin{tabular}{|c|c|c|c|}
\hline Етап дослідження & 1 етап & 2 етап & 3 етап \\
\hline Показники & $M_{e}[25 \% ; 75 \%]$ & $M_{e}[25 \% ; 75 \%]$ & $M_{e}[25 \% ; 75 \%]$ \\
\hline Mo, $c$ & $0,78[0,73 ; 0,83]$ & $0,78[0,75 ; 0,81]$ & $0,77[0,74 ; 0,81]$ \\
\hline AMo, \% & $35,25[32,32 ; 38,04]$ & $36,14[33,31 ; 38,53]$ & $37,19[34,32 ; 41,31]$ \\
\hline $\mathrm{BP}, c$ & $0,27[0,23 ; 0,32]$ & $0,26[0,22 ; 0,31]$ & $0,26[0,23 ; 0,28]$ \\
\hline Інапр. ум.од & $83,84[75,29 ; 100,20]$ & $90,51[80,21 ; 101,51]$ & $92,06[80,87 ; 103,48]$ \\
\hline 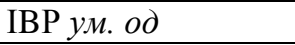 & $135,04[120,02 ; 161,89]$ & $140,37[127,36 ; 159,48]$ & $142,62[128,01 ; 159,33]$ \\
\hline ПАПР ум.од & $45,36[42,58 ; 49,21]$ & $47,44[41,32 ; 48,84]$ & $48,02[44,12 ; 52,63]$ \\
\hline
\end{tabular}

Примітка. Вірогідність відмінностей між показниками: ' - вихідними й наступними в межах кожної групи на рівні похибки: "-p $\leq 0,05$.

У студенток I та II груп на першому етапі досліджувані показники засвідчили відсутність напруження регуляторних систем, адекватність процесів регуляції (табл. 2, 4) та незначне переважання активності СВНС, обумовлене, на нашу думку, новою ситуацією, у яку потрапили вчорашні абітурієнти: умови життя, нові вимоги, зростання інформаційного навантаження.

Таблиця 3

Показники варіабельності серцевого ритму студенток з нормальною масою тіла в динаміці другого семестру

\begin{tabular}{|c|c|c|c|}
\hline $\begin{array}{c}\text { Етап } \\
\text { дослідження }\end{array}$ & 4 етап & 5 етап & 6 етап \\
\hline Показник & $M_{e}[25 \% ; 75 \%]$ & $\mathrm{M}_{\mathrm{e}}[25 \% ; 75 \%]$ & $\mathrm{M}_{\mathrm{e}}[25 \% ; 75 \%]$ \\
\hline Mo, $c$ & $0,77[0,73 ; 0,83]$ & $0,79[0,75 ; 0,85]$ & $0,78[0,75 ; 0,81]$ \\
\hline AMo, \% & $36,12[33,65 ; 38,32]$ & $36,96[32,43 ; 38,36]$ & $35,39[31,54 ; 38,44]$ \\
\hline $\mathrm{BP}, \mathrm{c}$ & $0,28[0,24 ; 0,34]$ & $0,26[0,24 ; 0,29]$ & $0,26[0,23 ; 0,29]$ \\
\hline Інапр. $y$ м. од & $82,37[77,75 ; 98,39]$ & $86,62[80,68 ; 92,40]$ & $82,77[82,45 ; 94,53]$ \\
\hline IBP ум.од & $133,88[113,52 ; 153,49]$ & $135,77[120,46 ; 142,99]$ & $135,82[129,29 ; 151,50]$ \\
\hline ПАПР $y м . o \partial$ & $46,89[44,63 ; 49,28]$ & $44,69[38,92 ; 50,98]$ & $46,17[41,89 ; 48,80]$ \\
\hline
\end{tabular}

Примітка. Вірогідність відмінностей між показниками: ' - вихідними й наступними в межах кожної групи на рівні похибки: '- $\mathrm{p} \leq 0,05$. 
Порівняльним аналізом вихідних величин із величинами, отриманими під час другого, третього й наступних досліджень, установлено на другому етапі в I групі тенденцію до зростання активності CB BНC, про що свідчило збільшення IBP; зростання Інапр. Проте значущих змін не встановлено (табл. 2). Про посилення мобілізаційного впливу СВ ВНС у досліджуваних II групи на цьому етапі дослідження свідчило значуще зростання AMo $(\mathrm{p} \leq 0,05)$ (табл. 4), що також указувало на зниження варіабельності серцевого ритму й адаптаційних можливостей організму та зростання ПАПР ( $\leq \leq 0,05)$ (табл. 4). Посилення активності СВ ВНС у студенток досліджуваних груп є закономірним, адже загальновизнано, що інтенсивна навчальна діяльність супроводжується комплексом вегетативних зрушень [15]. Крім того, установлені функціональні зрушення, на нашу думку, обумовлені тривалою дією нових чинників: нових форм і методів навчання, нових емоційних переживань, зміни режиму праці й відпочинку, сну та харчування, адаптацією до нового колективу.

Таблиия 4

Показники варіабельності серцевого ритму студенток із надмірною масою тіла протягом першого семестру

\begin{tabular}{|c|c|c|c|}
\hline $\begin{array}{c}\text { Етап } \\
\text { дослідження }\end{array}$ & 1 етап & 2 етап & 3 етап \\
\hline Показник & $M_{e}[25 \% ; 75 \%]$ & $\mathrm{M}_{\mathrm{e}}[25 \% ; 75 \%]$ & $\mathrm{M}_{\mathrm{e}}[25 \% ; 75 \%]$ \\
\hline Mo, $c$ & $0,77[0,71 ; 0,81]$ & $0,69[0,64 ; 0,79]$ & $0,67[0,63 ; 0,75]^{-\nabla}$ \\
\hline AMo, $\%$ & $33[31 ; 38]$ & $42[35 ; 50]^{\bullet}$ & $40,8[35,00 ; 47,00]$ \\
\hline $\mathrm{BP}, c$ & $0,25[0,22 ; 0,26]$ & $0,24[0,21 ; 0,27]$ & $0,23[0,19 ; 0,26]$ \\
\hline Інапр. $у м . ~ о д ~$ & $100,06[80,21 ; 101,51]$ & $132,31[108,73 ; 162,72]^{\circ}$ & $140,64[107,20 ; 168,30]^{-}$ \\
\hline IBP ум.од & $143,71[130,32 ; 159,48]$ & $180,12[147,31 ; 195,47]^{\diamond}$ & $190,88[154,32 ; 216,70]^{\diamond}$ \\
\hline 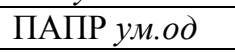 & $45,18[41,00 ; 48,02]$ & $60,09[47,28 ; 77,86]^{\mathbf{~}}$ & $58,68[47,86 ; 79,58]^{\mathbf{~}}$ \\
\hline
\end{tabular}

Примітка. Вірогідність відмінностей між показниками: ' - вихідними й наступними в межах кожної групи, ${ }^{\diamond}$ - першокурсниць I і II груп на кожному етапі дослідження на рівні похибки: ${ }^{(\diamond)}-\mathrm{p} \leq 0,05 ;{ }^{(\bullet}(\diamond \diamond)$ $\mathrm{p} \leq 0,01 ; \quad \cdots(\otimes 00)-\mathrm{p} \leq 0,001$.

Результати, отримані на третьому етапі дослідження (табл. 2, 4), який передував закінченню першого семестру, свідчили, що в представниць I і II груп урівноважування організму із зовнішнім середовищем відбувалося за допомогою активації адаптаційних реакцій організму. Проте отримані дані вказували на різний стан компенсаторно-адаптаційних механізмів. Так, адаптація студенток I групи відбувалася без суттєвого напруження механізмів регуляції, про що свідчили Мо, АМо, Інапр., величини яких значуще від вихідних не відрізнялися. Тоді як у II групі (табл. 4) установлено суттєве напруження компенсаторно-адаптаційних механізмів організму в межах фізіологічної форми, а саме підвищення активності механізмів симпатичної регуляції та зростання ступеня централізації управління серцевим ритмом, на що вказував ПАПР (p $\leq 0,05)$ (табл. 4), що залишався значуще вищим, порівняно з вихідним, та значуще зростання Інапр. ( $\leq \leq 0,05)$ (табл. 4), порівняно з вихідним.

Таблиця 5

Показники варіабельності серцевого ритму досліджуваних студенток із надмірною масою тіла протягом другого семестру

\begin{tabular}{|c|c|c|c|}
\hline $\begin{array}{c}\text { Етап } \\
\text { дослідження }\end{array}$ & 4 етап & 5 етап & 6 етап \\
\hline Показник & $M_{e}[25 \% ; 75 \%]$ & $\mathrm{M}_{\mathrm{e}}[25 \% ; 75 \%]$ & $M_{e}[25 \% ; 75 \%]$ \\
\hline Mo, c & $0,69[0,66 ; 0,77]^{\diamond}$ & $0,73[0,68 ; 0,77]^{\diamond}$ & $0,71[0,69 ; 0,77]$ \\
\hline AMo, $\%$ & $38,03[35,00 ; 46,00]$ & $39,83[37,00 ; 43,00]$ & $41,17[36,00 ; 46,00]$ \\
\hline $\mathrm{BP}, \mathrm{c}$ & $0,22[0,19 ; 0,26]$ & $0,23[0,18 ; 0,25]$ & $0,22[0,19 ; 0,25]$ \\
\hline Інапр. ум. од & $131,71[101,35 ; 189,96]^{\otimes}$ & $132,50[98,38 ; 176,09]^{\otimes}$ & $138,55[104,32 ; 183,25]^{-\otimes}$ \\
\hline ІВР ум.од & $176,79[139,73 ; 252,19]^{\diamond}$ & $192,31[147,29 ; 235,75]^{\mathbf{}}$ & $191,72[147,76 ; 254,58]^{-\otimes}$ \\
\hline ПАПР ум.од & $58,61[45,28 ; 69,30]^{\mathbf{*}}$ & $55,42[49,43 ; 64,24]$ & $56,84[49,48 ; 62,41]^{-\otimes 0}$ \\
\hline
\end{tabular}

Примітка. Вірогідність відмінностей між показниками: " - вихідними й наступними в межах кожної групи, ${ }_{-}^{\diamond}$ першокурсниць I і II груп на кожному етапі дослідження на рівні похибки: - $(\diamond)-p \leq 0,05 ; \boldsymbol{- \varpi}^{(\diamond \diamond)}-\mathrm{p} \leq 0,01$; - $(\Delta \diamond \bullet)-p \leq 0,001$. 
Аналіз результатів (табл. 3), отриманих після завершення канікул, на четвертому етапі дослідження в I групі не виявив ні тенденції до посилення напруження регуляторних механізмів, ні, тим більше, значущих змін показників варіабельності серцевого ритму. У той час як у II групі фіксували значуще вищу активність механізмів симпатичної регуляції. Про це свідчили значуще вищі, порівняно з вихідним, AMo (p $\leq 0,05)$ (табл. 5) і ПАПР (p $\leq 0,05)$ (табл. 5). Проте встановлено зменшення ступеня централізації управління серцевим ритмом, на що вказував I напр. (p $\leq 0,05)$ (табл. 5) який відновився до вихідного рівня, що стало можливим за рахунок відновлення тонусу ПС ВНС до вихідного рівня, що підтвердила величина Мо (табл. 5), то ж зимові канікули позитивно вплинули на організм досліджуваних.

На п'ятому й шостому етапах дослідження значущих змін показників варіабельності серцевого ритму в I групі не встановлено (табл. 3). Разом із тим у II групі на п'ятому етапі вперше виявили значуще зростання величини IBP (p $\leq 0,05)$ (табл. 5), порівняно з вихідною. Крім того, АМо $(\mathrm{p} \leq 0,05)$ (табл. 5), ПАПР (p $\leq 0,05)$ (табл. 5), Інапр. ( $\mathrm{p} \leq 0,05)$ (табл. 5) залишалися значуще вищими, порівняно 3 вихідними, що вказувало на високу активність СВ ВНС та суттєве напруження компенсаторно-адаптаційних механізмів організму, яке зберігалося й на останньому етапі дослідження. Виявлені зміни показників серцевого ритму в II групі можна кваліфікувати як перехід від суттєвого напруження компенсаторно-адаптаційних механізмів організму в межах фізіологічної норми до нестійкого, неповного пристосування, активного пошуку стійкого стану. Ці дані узгоджуються з такими Глазкова E. O., 2013.

За результатами непараметричного аналога дисперсійного аналізу критерієм Крускал-Уоліса ANOVA, найбільш чутливими до впливу маси тіла виявилися такі показники стану ССС. На першому етапі дослідження групи не відрізнялися за індексом напруження. Проте вже на другому етапі відмінності встановлені (табл. 4). Так, у II групі фіксований Інапр. (p<0,05) значуще вищий, порівняо з I групою. Виявлені відмінності зберігалися впродовж навчального року (табл. 4, 5). Це, згідно з Р. М. Баєвського, свідчило, що чим більша централізація управління серцевим ритмом, тим більше напруження регуляторних механізмів, тим вища «фізіологічна ціна адаптації».

Відомо, що фізіологічна «ціна» адаптації за умови високої реактивності СВ ВНС залежить від вираженості парасимпатичного відділу ВНС [6, с. 116]. Відповідно, нами виявлено, що величина Мо на першому етапі дослідження в студенток II групи від студенток I групи значуще не відрізнялася. Отримані результати також свідчили про відсутність значущих відмінностей активності ПВ ВНС у студенток із різною масою тіла на початку навчального року. Проте в II групі, починаючи з третього етапу дослідження, виявили значуще меншу величину Мо (p<0,05), порівняно 3 I групою (табл. 4, 5), що вказувало на більш виражений тонус ПВ ВНС у I групі, порівняно 3 II.

При порівнянні показників IBP, ПАПР, які відображають участь симпатичного або парасимпатичного, а також гуморального ланцюгів у регуляції серцевого ритму, виявлено, що на першому етапі дослідження їхні величини в представниць досліджуваних груп значуще не відрізнялися. Проте, починаючи 3 другого етапу, у II групі реєстрували значуще вищий IBP (p<0,05), ніж в I (табл. 4). А на останньому етапі - у II групі ПАПР ( $<0,05)$ також був вищий, ніж у I (табл. 5). Отже, отримані дані вказували на більш адекватне функціонування серця, студенток I групи, порівняно 3 II.

Отримані нами показники збігаються з даними Е. О. Глазкова, який, досліджуючи адаптацію студентів першого курсу, указує на те, що адаптація студентів до навчальної діяльності супроводжується послабленням холінергічних впливів і на перший план виступає підвищення активності адренергічних механізмів регуляції синусового ритму (Глазков Е. О., 2013). Також отримані дані узгоджуються з такими А. А. Артеменкова [2].

Дослідники у своїх працях указують на те, що успішність адаптації залежить від вихідного тонусу: підвищений симпатичний тонус призводить до напруження регуляторних систем, нормотонія - мінімальне напруження систем регуляції [10, с. 47]. Проте нами показано, що, незважаючи на однаковий вихідний тонус вегетативного відділу НС, адаптація студенток із різною масою тіла має свої особливості. Так, у динаміці навчального року в I групі встановлена лише тенденція до напруження компенсаторно-адаптаційних механізмів, у той час як у II групі виявлене, починаючи 3 другого етапу дослідження, значуще напруження компенсаторно-адаптаційних механізмів. Зміни показників серцевого ритму у II групі на останніх етапах дослідження можна кваліфікувати як перехід від суттєвого напруження компенсаторно-адаптаційних механізмів організму в межах фізіологічної норми до нестійкого, неповного пристосування, активного пошуку стійкого стану. Крім того, порівняльний аналіз показ- 
ників варіабельності серцевого ритму студенток із різним IMT на кожному етапі дослідження виявив: починаючи 3 другого етапу, у студенток II групи, порівняно з I, значуще менш виражений тонус ПВ ВНС, менш адекватне функціонування серця, більша централізація управління серцевим ритмом. Отже, у II групі напруження регуляторних механізмів, порівняно з I, було значуще вищим упродовж першого навчального року, а отже, i «фізіологічна ціна адаптації» вища. Відомо, що зростання ступеня напруження регуляторних механізмів тим більш виражено, чим менші функціональні резерви [1]. На основі зазначеного можна припустити, що функціональні резерви в студенток II групи нижчі, порівняно з I. Водночас значуще вище напруження регуляторних механізмів у II групі, порівняно з I, імовірно, зумовлене надмірною кількістю жирової тканини, яка вже за звичайних умов потребує посиленого кровозабезпечення [15] і в стресовій ситуації, коли зростають потреби в додатковому енергозабезпеченні, напруження регуляторних механізмів зростає.

Висновки та перспективи подальших досліджень. Адаптація студенток із нормальною масою тіла відбувалася без значущого напруження компенсаторно-адаптаційних механізмів, а в студенток із надмірною масою тіла - супроводжувалася значущим напруженням компенсаторно-адаптаційних механізмів. У студенток із надмірною масою тіла, порівняно з особами з нормальною масою тіла, напруження регуляторних механізмів було значуще вищим упродовж першого навчального року, а отже, «фізіологічна ціна адаптації» вища. Можна вважати, що студентки 3 надмірною масою тіла входять у групу ризику розвитку психосоматичних захворювань, що вимагає впровадження індивідуального підходу та індивідуальних навчальних програм з окремих дисциплін та особливо ідивідуальних програм на заняттях із фізичного виховання при організації навчального процесу.

Дослідження змін варіабельності серцевого ритму в першокурсниць із різним IMT протягом першого року навчання дасть змогу розкрити особливості процесів адаптації в цієї категорії студенток.

\section{Джерела та література}

1. Агаджанян Н. А. Функциональные резервы организма и теория адаптации / Н. А. Агаджанян, Р. М. Баєвский, А. П. Берсенева // Вестник востановительной медицины. - 2004. - № 3(9). - С. 4-10.

2. Артеменков А. А. Оценка функционального состояния и резервных возможностей студентов в разные периоды обучения в вузе / А. А. Артеменков // Профилактическая медицина. - 2013. - № 3. - С. 33-36.

3. Баевский Р. М. Оценка адаптационных возможностей организма и риск развития заболевания : [пособие] / Р. М. Баевский, А. П. Берсенева. - М. : Медицина, 1997. - 251 с.

4. Басвський Р. М. Аналіз варіабельності серцевого ритму при використанні різних кардіографічних систем [метод. рек.] / Р. М. Баєвський, Г. Г. Іванов, Л. В. Чирейкін, А. П Гаврилушкін, П. Я. Довгалевський, Ю. Я. Кукушкін // Вісник аритмології. - № 24. - 2001. - С. 65-87.

5. Большова О. В. Ожиріння в дитячому та підлітковому віці / О. В. Большова // Здоров'я України. 2008. - № 18/1. - C. 50-53.

6. Бернада В. Вегетативне забезпечення розумової діяльності студентів молодших курсів з різною швидкістю опрацювання інформації / В. Бернада // Вісник Львівського університету. - Серія : біологічна. Вип. 24. - 2006. - С.109-117.

7. Глазков Е. О. Варіабельність серцевого ритму та загальна реактивність організму студентів у процесі адаптації до навчання у вищих навчальних закладах / Глазков Е. О. // Український журнал клінічної та лабораторної медицини. - 2013. - Т 8, №1. - С. 196-199.

8. Гиріна О. М. Поширеність ожиріння як чинник ризику соматичної патології серед підлітків / О. М. Гиріна, А. В. Громович // Практикуючий лікар. - 2012. - № 2. - С. 32-35.

9. Горбась I. М. Фактори ризику серцево-судинних захворювань: поширеність і контроль / I. М. Горбась // Здоровье Украины. - 2007. - № 21/1 (ноябрь). - С. 62-63.

10. Ісаков О. А. Вегетативні прояви реакції термінової адаптації студентів до інформаційного навантаження / О. А. Ісаков, В. П. Ляшенко, Г. С. Петров // Вчені записки Таврійського національного університету ім. В. І. Вернадського. - Серія : «Біологія, хімія». - 2013. - Т. 26 (65), № 4. - С. 46-59.

11. Корягін В. М. Оптимізація навчального процесу на заняттях спеціальних медичних груп вузу із студентами, хворими на ожиріння / В. М. Корягін, О. З. Блавт, Л. П. Цьовх, Т. В. Гуртова // Слобожанський науково-спортивний вісник, - Х., ХДАФК, 2010. - № 1. - С. 79-86.

12. Мунтян В. С. Особенности формирования положительной мотивации студентов к физическому воспитанию / В. С. Мунтян // Вісник Чернігівського національного педагогічного університету імені Т. Г. Шевченка. Чернигов : ЧНПУ, 2013. - Т. 98 (1). - С. 100-120.

13. Нагорна I. С. Ожиріння як соціальна проблема сучасної молоді. Сучасне українське студентство: проблеми та ціннісні орієнтації : тези доп. V Всеукр. наук.-практ. конф. студ. та молодих вчених / I. С. Нагорна. - Хмельницький : ХІСТ, 2011. - С. 182-185. 
14. Синайко В. М Особенности динамики психического состояния студентов медицинского вуза / В. М. Синайко // Український вісник психоневрології. - 2001. - Т. 9, вип. 2(27). - С. $42-44$.

15. Diabel L. N. Effect of increased intraabdominal pressure on hepatic arterial, portal venous, and hepatic microcirculatory blood flow / R. F. Wilson, S. A. Dulchavsky, J. Saxe // Trauma. - 2002. - Vol. 33. - P. $279-283$.

16. Hjortskov N. The effect of mental stress on heart rate variability and blood pressure during computer work / N. Hjortskov, D. Rissen, A.K. Blang'sted, N. Fallentin, U. Lundberg, K. Sogaard // Eur. J. Appl. Physiol. 2004. - V 92, № 1-2. - P 84-89.

17. Matsumoto T. Altered autonomic nervous system activity as a potential etiological factor of premenstrual syndrome and premenstrual dysphoric disorder / T. Matsumoto, T. Ushiroyama, T. Kimura, T. Hayashi and T. Moritani // BioPsychoSocial Medicine. - 2007. - No. 1 (24). - P.1-24.

Добростан Оксана, Плиска Александр, Филимонова Наталия. Адаптационные реакции организма студенток с разной массой тела в динамике первого года обучения. Отклонение массы тела от нормы имеет существенное значение в ситуациях, которые предъявляют повышенные требования к организму человека. Поэтому цель нашего исследования заключалась в изучении адаптационных реакций организма студенток с разной массой тела в динамике первого года обучения на основе анализа степени напряжения регуляторных систем. Для проведения исследования из числа студенток первого курса НПУ им. М. П. Драгоманова сформированы две группы: I - студентки с нормальной массой тела, II - студентки с избыточной массой тела. В динамике учебного года в I группе установлена только тенденция к напряжению компенсаторно-адаптационных механизмов, в то время как во II выявлено, начиная со второго этапа исследования, значимое напряжение компенсаторно-адаптационных механизмов. Выявленные изменения показателей сердечного ритма во II группе на последних этапах исследования можно квалифицировать как переход от существенного напряжения компенсаторно-адаптационных механизмов организма в пределах физиологической нормы в непрочное приспособления. Кроме того, сравнительный анализ показателей вариабельности сердечного ритма студенток с разным ИМТ на каждом этапе исследования показал: начиная со второго этапа, у студенток II группы, по сравнению с I, значимо менее выраженный тонус ПО ВНС, менее адекватное функционирование сердца, большую централизацию управления сердечным ритмом. Итак, в II группе по сравнению с I группой напряжения регуляторных механизмов было значимо выше в течение первого учебного года, а следовательно, «физиологическая цена адаптации» выше. Таким образом, можно считать, что студентки с избыточной массой тела входят в группу риска развития психосоматических заболеваний, что требует внедрения индивидуального подхода и индивидуальных учебных программ по отдельным дисциплинам и, особенно, идивидуальных программ на занятиях по физическому воспитанию при организации учебного процесса.

Ключевые слова: адаптация, регуляторные механизмы, степень напряжения, студентки.

Dobrostan Oksana, Pluska Oleksandr, Filimonova Natalay. Adaptation Responses of Student's Organisms with Different Weight in the Dynamics of the First Year of Study. A deviation in body weight from a norm is essential in situations which put high demands to a human body. Therefore, the purpose of our research was to study adaptive responses of students with different weight in the dynamics of the first year of study by analyzing the degree of tension of regulatory systems. For the researchit was formed two groups from the number of students of the first year of M.P. Drahomanov NPU: I group has been consisted by students with normal body weight, II - students are overweight. The dynamics of the academic year in the I group is set only a tendency to intension the compensatoryadaptive mechanisms, while in the II group is found significant tension compensatory-adaptive mechanisms since the second phase of the study. Detected changes of heart rate in the II group in the last stages of the research can be described as a transition from substantial intension of compensatory-adaptive mechanisms of the organism within the physiological norm to unstable adaptation. In addition, a comparative analysis of heart rate variability students with different BMI at each stage of the study showed: starting from the second stage of the II group of students in comparison with I one a tone of parasympathetic divisionis much less expressed, less adequate functioning of the heart, more centralizationof heart rhythm control. Consequently, in the II group in comparison withthe I group the intensionof regulatory mechanisms was significantly higher during the first academic year, and therefore «price physiological adaptation» higher. In such a way we can assume that students are overweight are ina risk group of psychosomatic diseases, which demands the implementation of individual approach and individual studying programs in some disciplines, and especially individual programs physical training lessons during the educational process.

Key words: adaptation, regulatory mechanisms, the degree of stress student.

Стаття надійшла до редколегії 18.04.2016 p. 